\title{
A mismatch between population health literacy and the complexity of health information:
}

\author{
an observational study
}

\begin{abstract}
Background

Low health literacy is associated with poorer health and higher mortality. Complex health materials are a barrier to health
\end{abstract}

Aim

To assess the literacy and numeracy skills required to understand and use commonly used English health information materials, and to describe population skills in relation to these.

\section{Design and setting}

An English observational study comparing health materials with national working-age population skills.

\section{Method}

Health materials were sampled using a health literacy framework. Competency thresholds to understand and use the materials were identified. The proportion of the population above and below these thresholds, and the sociodemographic variables associated with a greater risk of being below the thresholds, were described

\section{Results}

Sixty-four health materials were sampled. Two competency thresholds were identified: text (literacy) only, and text + numeracy; 2515/5795 participants (43\%) were below the text-only threshold, while 2905/4767 (61\%) were below the text + numeracy threshold. Univariable analyses of social determinants of health showed that those groups more at risk of socioeconomic deprivation had higher odds of being below the health literacy competency threshold than those at lower risk of deprivation. Multivariable analysis resulted in some variables becoming non-significant or reduced in effect.

\section{Conclusion}

Levels of low health literacy mirror those found in other industrialised countries, with a mismatch between the complexity of health materials and the skills of the English adult working-age population. Those most in need of health information have the least access to it. Efficacious strategies are building population skills, improving health professionals communication, and improving written health information.

\section{Keywords}

health information; health literacy; numeracy; primary care; public health.

\section{INTRODUCTION}

Health literacy skills are the motivation and ability of individuals to access, understand, and use information in ways which promote and maintain good health'. ' The most fundamental skills are those "needed to function in everyday (health) situations to access and use information'? Low health literacy is associated with greater use of medical services, less preventive care, greater difficulty managing long-term illnesses, ${ }^{3}$ lower levels of health, ${ }^{3-5}$ and higher mortality in older people., Levels of health literacy have been surveyed in several industrialised countries, that is, the US, Canada, Australia, and the EU, with the prevalence of low health literacy varying from $29 \%$ to $62 \%{ }^{5-8}$

Health texts are written at levels that exceed average public readings skills. 9.10 Finding ways to reduce the mismatch between population skills and health material complexity has been identified as a priority by the US government. ${ }^{11}$

This study sought to explore health literacy skills in an English setting, bringing together expertise from clinical practice, public health, and education. The objectives were to assess a range of health materials; to determine the threshold of health literacy

G Rowlands, FRCGP, FRCP, MD, professor, Institute of Public Health, Aarhus University, Aarhus, Denmark and Institute for Health and Society, Newcastle University, Newcastle, UK J Protheroe, MRes, PhD, FRCGP, senior lecturer in general practice, Research Institute for Primary Health Care \& Health Sciences, Keele University, Keele, UK. J Winkley, BSc, MEng, FCIEA, director. AlphaPlus Consultancy Ltd, Manchester, UK. M Richardson, BSc, MSc, statistician, Liverpool Reviews and Implementation Group, University of Liverpool, Liverpool, UK. PT Seed, BSc, MSc, CStat, senior lecturer in medical statistics, Division of Women's Health, King's College London, London UK. RE Rudd, BA, MSPH, ScD, senior lecturer on health literacy, education, and policy, Harvard and numeracy skills needed to understand and use these; and to describe the English working-age population in relation to these thresholds.

\section{METHOD}

Health materials in England were purposively sampled using a framework developed to capture literacy and numeracy skills needed to become and stay healthy. ${ }^{12}$ This framework has been used in several national health literacy surveys. ${ }^{6-8}$ Suitable topics within framework areas ffor example, within health promotion: how to maintain a healthy weight) were discussed and agreed by the research team. Materials from topics within each framework area were independently sampled. All items were nationally publicly available in health and public libraries or via the internet. The framework, with examples and chosen subjects, is shown in Box 1.

The sampled materials were independently assessed by external experts, that is, people at a senior level (consultant or equivalent) in areas of relevance to health literacy. Health trainers (non-clinical workers providing self-management advice and signpostingl were included. Prior knowledge of health
School of Public Health, Department of Social and Behavioral Sciences, Boston, MA, US

\section{Address for correspondence}

Gillian Rowlands, Institute of Health and Society, Baddiley-Clark Building, Newcastle upon Tyne, Tyne and Wear NE2 4AX, UK.

E-mail: Gill.Rowlandsanewcastle.ac.uk Submitted: 31 July 2014; Editor's response: 7 October 2014; final acceptance: 11 November 2014.

OBritish Journal of General Practice

This is the full-length article (published online 26 May 2015) of an abridged version published in print. Cite this article as: $\mathbf{B r} \mathbf{J}$ Gen Pract 2015; DOI: 10.3399/bjgp15X685285 


\section{How this fits in \\ Low health literacy is associated with lower levels of health, higher risk of long-term conditions, more difficulty managing conditions, and, in older people, higher mortality. This study explored the extent to which the level of literacy and numeracy required to understand and use health information in England matched the literacy and numeracy skills of the population. A significant proportion of the population did not have the skills to fully understand and use the health materials sampled. A rigorous approach should be taken to develop more accessible health information, and further research should explore the health and economic impact of low health literacy in England.}

literacy was not required. Experts were approached through the UK health literacy group, a national group of researchers, practitioners, and patient groups, ${ }^{13}$ via an email to members with an NHS email. Experts were also recruited through local

\begin{tabular}{|c|c|c|c|c|}
\hline $\begin{array}{l}\text { Health } \\
\text { activities }\end{array}$ & Focus & Examples of materials & Examples of tasks & Subject areas \\
\hline \multirow{2}{*}{$\begin{array}{l}\text { Health } \\
\text { Promotion }\end{array}$} & \multirow{2}{*}{$\begin{array}{l}\text { Enhance and } \\
\text { maintain health }\end{array}$} & - Charts, graphs, lists & - Purchase food & \multirow[t]{2}{*}{ - Healthy weight } \\
\hline & & - Food and product labels & - Plan exercise regimen & \\
\hline \multirow{3}{*}{$\begin{array}{l}\text { Protecting } \\
\text { personal and } \\
\text { public safety }\end{array}$} & \multirow{3}{*}{$\begin{array}{l}\text { Safeguard health } \\
\text { of individuals and } \\
\text { communities }\end{array}$} & - Health and safety & \multirow{2}{*}{$\begin{array}{l}\text { - Decide between product } \\
\text { options }\end{array}$} & \multirow{3}{*}{$\begin{array}{l}\text { - Road safety } \\
\text { - Home safety }\end{array}$} \\
\hline & & warnings & & \\
\hline & & $\begin{array}{l}\text { - Air and water quality } \\
\text { reports }\end{array}$ & - Use/avoid products & \\
\hline \multirow{6}{*}{$\begin{array}{l}\text { Disease } \\
\text { prevention }\end{array}$} & \multirow{6}{*}{$\begin{array}{l}\text { Take preventive } \\
\text { measures and } \\
\text { engage in early } \\
\text { detection }\end{array}$} & \multirow{3}{*}{$\begin{array}{l}\text { - Postings for } \\
\text { inoculations and } \\
\text { screening } \\
\text { - Letters related to test } \\
\text { results }\end{array}$} & - Determine risk & \\
\hline & & & $\begin{array}{l}\text { - Engage in screening or } \\
\text { diagnostic tests }\end{array}$ & \multirow{4}{*}{$\begin{array}{l}\text { - Cancer } \\
\text { screening } \\
\text { - Reduction in } \\
\text { harmful } \\
\text { lifestyle } \\
\text { activities }\end{array}$} \\
\hline & & & - Follow-up & \\
\hline & & \multirow[t]{3}{*}{ - Graphs, charts } & & \\
\hline & & & & \\
\hline & & & & - Vaccination \\
\hline \multirow[t]{3}{*}{$\begin{array}{l}\text { Managing } \\
\text { illness }\end{array}$} & \multirow{3}{*}{$\begin{array}{l}\text { Seek care } \\
\text { and form a } \\
\text { partnership } \\
\text { with healthcare } \\
\text { providers }\end{array}$} & $\begin{array}{l}\text { - Health history forms } \\
\text { - Medicine labels }\end{array}$ & $\begin{array}{l}\text { - Describe and measure } \\
\text { symptoms }\end{array}$ & \multirow{3}{*}{$\begin{array}{l}\text { - Diabetes } \\
\text { mellitus } \\
\text { - Medication } \\
\text { instructions }\end{array}$} \\
\hline & & - Discharge instructions & $\begin{array}{l}\text { - Follow directions on } \\
\text { medicine labels }\end{array}$ & \\
\hline & & $\begin{array}{l}\text { - Education booklets and } \\
\text { brochures }\end{array}$ & $\begin{array}{l}\text { - Collect information on } \\
\text { merits of various treatment } \\
\text { regimens for discussion } \\
\text { with health professionals }\end{array}$ & \\
\hline \multirow{4}{*}{$\begin{array}{l}\text { Systems } \\
\text { navigation }\end{array}$} & \multirow{4}{*}{$\begin{array}{l}\text { Access needed } \\
\text { services }\end{array}$} & - Maps & - Locate facilities & \multirow{4}{*}{$\begin{array}{l}\text { - Which services } \\
\text { to access } \\
\text { when acutely } \\
\text { unwell, and } \\
\text { how to access } \\
\text { them }\end{array}$} \\
\hline & & - Application forms & - Apply for benefits & \\
\hline & & $\begin{array}{l}\text { - Statements of rights } \\
\text { and responsibilities }\end{array}$ & - Offer informed consent & \\
\hline & & - Informed consent & & \\
\hline
\end{tabular}

contacts in London and Manchester. Fiftytwo experts were approached, of which 33 (63\%) agreed to participate. They consisted of seven nurses, six GPs, six hospital consultants, five dieticians/nutritionists, two NHS managers, two road safety experts, two health trainers, two health promotion experts, and one public health consultant.

Experts were asked whether the materials represented those in everyday use, the frequency with which people would be exposed to the material, and the potential impact of failure to understand and use the information. They were asked to identify areas where additional material should be sampled. Additional sampling and assessment followed the same protocol. Views were gathered through a web-based survey.

All the materials were assessed for their literacy and numeracy complexity using the English National Qualifications Framework (NQF) ${ }^{14}$ by education experts external to the study team (Box 2).

Education reviewers assessed the level of skill required to understand and use the materials. These were graded up to and including level 2, the level expected to be achieved by age 16 years; materials above this level were grouped with level 2. Each item was assessed by one reviewer using standard criteria for the NQF. Areas of ambiguity, or where assessment was 'borderline' between skills levels, were highlighted and discussed. The materials were not tested directly with SFL 2011 participants. Data on skills were taken directly from The 2011 Skills for Life Survey (SFL 2011) data. Further details are available from the authors.

\section{Population health literacy competency}

A competency threshold of $70 \%$ was adopted, reflecting usual English practice, and similar to the US threshold of $67 \%$. $^{15}$ This made allowances for testing errors, assumed that understanding most health materials would be sufficient for 'competency', and mitigated against chance sampling of overly complex materials.

Each item was coded and a basic and cumulative frequency of the number of materials at each skills level tabulated, weighted according to expert health panel assessments. The proportion of the population above and below these competency thresholds were derived from SFL 2011 (Box 3). ${ }^{16}$

SFL 2011 data were weighted to ensure they were representative of the English resident working-age population. Statistical analyses were undertaken using IBM PASW 


\begin{tabular}{|c|c|c|c|c|}
\hline Level & $\begin{array}{l}\text { English NQF } \\
\text { age equivalent }\end{array}$ & $\begin{array}{l}\text { Literacy } \\
\text { An adult classified at the } \\
\text { level understands }\end{array}$ & $\begin{array}{l}\text { Numeracy } \\
\text { An adult classified at the } \\
\text { level understands }\end{array}$ & $\begin{array}{l}\text { Examples of } \\
\text { typical skills }\end{array}$ \\
\hline \multirow[t]{2}{*}{ Entry 1} & \multirow[t]{2}{*}{$5-7$ years } & $\begin{array}{l}\text { - Short texts with repeated } \\
\text { language patterns on }\end{array}$ & \multirow{2}{*}{$\begin{array}{l}\text { - Information given by numbers } \\
\text { and symbols in simple } \\
\text { graphical, numerical, and } \\
\text { written material }\end{array}$} & \multirow{2}{*}{$\begin{array}{l}\text { - Write short } \\
\text { messages } \\
\text { - Select floor } \\
\text { numbers } \\
\text { in lifts }\end{array}$} \\
\hline & & $\begin{array}{l}\text { familaar topics } \\
\text { - Information from common } \\
\text { signs and symbols }\end{array}$ & & \\
\hline \multirow[t]{2}{*}{ Entry 2} & \multirow[t]{2}{*}{ 7-9 years } & $\begin{array}{l}\text { - Short straightforward texts } \\
\text { on familiar topics }\end{array}$ & \multirow{2}{*}{$\begin{array}{l}\text { - Information given by numbers, } \\
\text { symbols, simple diagrams, and } \\
\text { charts in graphical, numerical, } \\
\text { and written material }\end{array}$} & $\begin{array}{l}\text { - Describe } \\
\text { health } \\
\text { symptoms }\end{array}$ \\
\hline & & $\begin{array}{l}\text { - Information from short } \\
\text { documents, familiar } \\
\text { sources, signs, and symbols }\end{array}$ & & $\begin{array}{l}\text { symptoms } \\
\text { - Use a } \\
\text { cashpoint } \\
\text { machine }\end{array}$ \\
\hline \multirow[t]{2}{*}{ Entry 3} & \multirow[t]{2}{*}{ 9-11 years } & $\begin{array}{l}\text { - Short straightforward texts } \\
\text { on familiar topics accurately } \\
\text { and independently }\end{array}$ & \multirow{2}{*}{$\begin{array}{l}\text { - Information given by numbers, } \\
\text { symbols, diagrams, and charts } \\
\text { used for different purposes and } \\
\text { in different ways in graphical, } \\
\text { numerical, and written material }\end{array}$} & \multirow{2}{*}{$\begin{array}{l}\text { - Understand } \\
\text { price labels } \\
\text { - Pay } \\
\text { household } \\
\text { bills }\end{array}$} \\
\hline & & $\begin{array}{l}\text { - Information from everyday } \\
\text { sources }\end{array}$ & & \\
\hline \multirow[t]{2}{*}{ Level 1} & \multirow[t]{2}{*}{$\begin{array}{l}\text { Matriculation } \\
\text { examinations } \\
\text { (GSCE) grade } \\
\text { D-G }\end{array}$} & $\begin{array}{l}\text { - Short straightforward texts } \\
\text { of varying length on a variety } \\
\text { of topics accurately and } \\
\text { independently }\end{array}$ & \multirow{2}{*}{$\begin{array}{l}\text { - Straightforward mathematical } \\
\text { information used for different } \\
\text { purposes. Independently select } \\
\text { relevant information from given } \\
\text { graphical, numerical, and written } \\
\text { material }\end{array}$} & \multirow[t]{2}{*}{$\begin{array}{l}- \text { GCSE } \\
\text { grades D-G }\end{array}$} \\
\hline & & $\begin{array}{l}\text { - Information from different } \\
\text { sources }\end{array}$ & & \\
\hline \multirow[t]{2}{*}{$\begin{array}{l}\text { Level } 2 \\
\text { or above }\end{array}$} & \multirow{2}{*}{$\begin{array}{l}\text { GCSE grades } \\
A^{*} \text { to } C \\
\text { or higher } \\
\text { qualifications }\end{array}$} & $\begin{array}{l}\text { - A range of texts of varying } \\
\text { complexity accurately and } \\
\text { independently }\end{array}$ & \multirow{2}{*}{$\begin{array}{l}\text { - Mathematical information used } \\
\text { for different purposes and can } \\
\text { independently select and } \\
\text { compare relevant information } \\
\text { from a variety of graphical, } \\
\text { numerical, and written material }\end{array}$} & \multirow[t]{2}{*}{$\begin{array}{l}\text { - } 5 \text { grades } A^{*} \\
\text { to C GCSE }\end{array}$} \\
\hline & & $\begin{array}{l}\text { - Can obtain information of } \\
\text { varying length and detail } \\
\text { from different sources }\end{array}$ & & \\
\hline
\end{tabular}

(version 19), SPSS (version 21), and Stata (version 12). Initial univariable analyses explored the association between low health

\section{Box 3. The Skills for Life 2011 \\ Survey ${ }^{16}$}

- Conducted between May 2010 and February 2011

- Survey population: all adults aged 16-65 years resident in England

- A figure of 7230 participants purposively sampled to reflect survey population

- Background sociodemographic information followed by a pre-assigned random combination of two of three skills assessments: literacy, numeracy, and information communication technology

- In total, 6049 responders assigned to literacy assessment, 6053 responders assigned to numeracy assessment, 4767 responders assigned to both literacy and numeracy assessments. literacy and known sociodemographic determinants of health $(\mathrm{SDH}),{ }^{17,18}$ that is, age, sex, ethnicity, nativity, first language, qualification level, employment, income, home ownership, and area of residence (Index of Multiple Deprivation) ${ }^{19}$ (Box 4).

The study identified a new variable, the 'Access to Information' (ATI) index. The SFL 2011 data included information on access to information sources (books, newspapers, and magazines), frequency of reading, and access to a computer and the internet. The ATI was an unweighted composite score.

Separate analyses were undertaken for literacy-only competency and for literacy + numeracy competency. For each variable, the odds of an individual being in the 'below threshold' group was calculated; odds ratios, with $95 \%$ confidence intervals (Cls) and statistical significance $(P<0.05)$, were then calculated, with the group with the lowest odds for being below the threshold being taken as the reference group.

Multivariable logistic regression explored which variables remained significant when all variables were considered together. Adjusted odds ratios, with $95 \% \mathrm{Cls}$ and statistical significance levels, were then calculated for each variable.

As an observational study, STROBE guidelines were followed. ${ }^{20}$

The health materials were all publicly available, and the SFL 2011 data were fully anonymised and publicly available. Ethics approval was therefore not required.

\section{RESULTS}

\section{Assessment of health materials}

Sixty-four health materials were sampled. All contained literacy (text) information, and 50 also contained numeracy information. No materials contained just numeracy information. All sampling framework areas contained both 'text-only' and 'text + numeracy' materials except health promotion, where all items were 'text + numeracy'. Details of the materials, the external expert assessments and weighting are shown in Table 1.

Health material representativeness was rated on a scale of 0 (not representative at all) to 3 (highly representative); mean scores ranged from 1.8 to 2.2. Weighting was calculated by multiplying 'frequency of exposure' by 'potential impact of failure to understand and use the material' (possible range 0-9); scores ranged from 3.6 to 5.0 .

Following weighting, 17 (27\%) of the text items were at NQF literacy level 1 or below, with $47(73 \%)$ at level 2 or above. The 'text-only' competency threshold was thus level 2. Weighted assessments of numeracy 


\begin{tabular}{ll}
$\begin{array}{l}\text { Box 4. Variables explored in the analysis } \\
\text { Variable }\end{array}$ & Categories \\
\hline Sex & Male, female \\
\hline Age & $16-44$ years, $\geq 45$ years and over \\
\hline Ethnicity & White, black and minority ethnic \\
\hline Nativity (Place of birth) & UK, outside of UK \\
\hline First language & English, other \\
\hline Qualification level & National Qualification Framework (NQF) at or above the \\
\hline Employment status & level expected by age 16years (level 2), NQF below level 2 \\
\hline Job status & Employed, not employed \\
\hline Gross individual income & National Statistics Socioeconomic Classification 3 bands \\
\hline Home ownership & $\geq € 10$ 000, $<€ 10$ 000 \\
\hline Area deprivation (Index of Multiple & Owns or part-owns home, does not own home \\
Deprivation score) & Quintiles \\
\hline
\end{tabular}

components showed that $20(39 \%)$ were at entry level 3 or below, and 30 (60\%) were at level 1 or above. The numeracy competency threshold was therefore level 1.

Thus two competency thresholds were identified; text-only materials (literacy level 2), and text + numeracy materials (literacy level $2+$ numeracy level 1 ).

\section{Population health literacy skills}

Analyses were undertaken separately for health literacy (text-only) and health literacy + numeracy. Results for both analyses were similar, therefore only the literacy-only results are presented here; the literacy + numeracy results are available from the author on request.

The characteristics of the sample for the variables analysed for the literacy threshold are shown in Table 2. Collection of data on participant characteristics and skills assessments were carried out as part of the SFL 2011 survey. ${ }^{16}$ Of those who took the literacy assessments, 2515/5795 (43\%) were below the text-only competency threshold. The levels of missing data, and the numbers of participants who failed to complete the tests, was low.

The characteristics of the sample for the variables analysed for the literacy + numeracy threshold, including missing data, are available from the author on request. Of those who took both the literacy and numeracy assessment, 2905/4767 participants (61\%) were below the literacy + numeracy competency threshold. The levels of missing data, and the numbers of participants who failed to complete the tests, was low.

\section{Univariable and multivariable analyses}

The unadjusted (univariable) and adjusted

Table 1. Health materials sampled

\begin{tabular}{|c|c|c|c|c|c|c|c|}
\hline \multirow[b]{2}{*}{ Health activities } & \multicolumn{3}{|c|}{ Material type } & \multirow{2}{*}{$\begin{array}{l}\text { Are these } \\
\text { materials } \\
\text { representative } \\
\text { of those in } \\
\text { everyday use? } \\
\text { Mean score }^{\text {a }}\end{array}$} & \multirow{2}{*}{$\begin{array}{l}\text { How many } \\
\text { patients } \\
\text { would be } \\
\text { exposed } \\
\text { to this } \\
\text { material? } \\
\text { Mean score }\end{array}$} & \multirow{2}{*}{$\begin{array}{l}\text { What is the } \\
\text { potential } \\
\text { impact of } \\
\text { failure to } \\
\text { understand } \\
\text { this material } \\
\text { Mean score }\end{array}$} & \multirow{2}{*}{$\begin{array}{c}\text { Weight } \\
\text { (frequency } \\
\text { of exposure } \\
\text { x potential } \\
\text { impact) } \\
\text { Range } \\
\text { 0-9d }\end{array}$} \\
\hline & $\begin{array}{l}\text { Text } \\
\text { only }\end{array}$ & $\begin{array}{c}\text { Text + } \\
\text { numeracy }\end{array}$ & Total & & & & \\
\hline Health promotion & 0 & 13 & 13 & 1.8 & 1.8 & 2.0 & 3.6 \\
\hline $\begin{array}{l}\text { Protecting personal } \\
\text { and public safety }\end{array}$ & 4 & 10 & 14 & 2.0 & 1.9 & 2.6 & 4.9 \\
\hline Disease prevention & 2 & 10 & 12 & 2.1 & 2.0 & 2.0 & 4.0 \\
\hline Managing illness & 3 & 12 & 15 & 2.2 & 2.0 & 2.4 & 4.8 \\
\hline Systems navigation & 5 & 5 & 10 & 2.1 & 2.1 & 2.2 & 4.6 \\
\hline Total & 14 & 50 & 64 & & & & \\
\hline
\end{tabular}




\section{Table 2. Literacy competency descriptive analyses}

\begin{tabular}{|c|c|c|}
\hline Category & $\begin{array}{l}\text { Below competency threshold } \\
\% \text { ( } n \text { below } / n \text { total) }\end{array}$ & $\begin{array}{l}\text { Skills test not completed/ } \\
\text { not recorded, } n\end{array}$ \\
\hline All & $43(2515 / 5795)$ & 255 \\
\hline \multicolumn{3}{|l|}{ Sex } \\
\hline Female & $41(1197 / 2907)$ & 137 \\
\hline Male & $45(1317 / 2887)$ & 118 \\
\hline \multicolumn{3}{|l|}{ Age, years ${ }^{a}$} \\
\hline $16-44$ & $57(1439 / 3500)$ & 149 \\
\hline $45-65$ & $43(1074 / 2292)$ & 106 \\
\hline \multicolumn{3}{|l|}{ Ethnicity ${ }^{a}$} \\
\hline White & $41(2032 / 4996)$ & 206 \\
\hline Black and minority ethnic & $61(481 / 795)$ & 49 \\
\hline \multicolumn{3}{|l|}{ Nativitya } \\
\hline Born in UK & $41(2010 / 4953)$ & 189 \\
\hline Not born in UK & $60(504 / 842)$ & 66 \\
\hline \multicolumn{3}{|l|}{ First language ${ }^{a}$} \\
\hline English & $40(2102 / 5200)$ & 203 \\
\hline Other than English & $69(412 / 594)$ & 52 \\
\hline \multicolumn{3}{|l|}{ Qualification levela } \\
\hline 5 grade A-C GCSE or above & $25(569 / 2306)$ & 199 \\
\hline Below 5 grade A-C GCSE & 56 (1945/3488) & 56 \\
\hline \multicolumn{3}{|l|}{ Employment ${ }^{a}$} \\
\hline In work & $39(1582 / 4061)$ & 184 \\
\hline Not in work & $54(932 / 1733)$ & 71 \\
\hline \multicolumn{3}{|l|}{ Job grade ${ }^{a}$} \\
\hline Managerial/professional & $28(602 / 2158)$ & 95 \\
\hline Intermediate & $43(438 / 1014)$ & 18 \\
\hline Routine/manual/students/unemployed & $56(1474 / 2622)$ & 142 \\
\hline \multicolumn{3}{|l|}{ Income $^{\mathrm{b}}$} \\
\hline$\geq € 10000$ & $20(806 / 4015)$ & 94 \\
\hline$<£ 10000$ & $96(1708 / 1779)$ & 161 \\
\hline \multicolumn{3}{|l|}{ Home ownership $p^{b}$} \\
\hline Owns or part-owns home & $35(1251 / 3593)$ & 155 \\
\hline Does not own home & $57(1263 / 2202)$ & 100 \\
\hline \multicolumn{3}{|l|}{ Area deprivation ${ }^{a}$} \\
\hline 0-9 (least deprived) & $29(362 / 1233)$ & 44 \\
\hline $10-19$ & $38(733 / 1906)$ & 87 \\
\hline $20-29$ & $44(460 / 1036)$ & 42 \\
\hline $30-39$ & $55(406 / 737)$ & 30 \\
\hline$\geq 40$ (most deprived) & $64(553 / 862)$ & 52 \\
\hline \multicolumn{3}{|l|}{ Access to information score ${ }^{a}$} \\
\hline$\geq 9$ (high access) & $27(499 / 1881)$ & 72 \\
\hline $5-8$ & $44(1208 / 2725)$ & 119 \\
\hline$<5$ (low access) & $68(807 / 1187)$ & 64 \\
\hline
\end{tabular}

Variable data missing (not entered or declined): ${ }^{a} n=0-10,{ }^{b} n=10$ to 20 . ethnic groups, those born outside the UK, without English as a first language, highest level of qualification below that expected by age 16 years, not in work, in low-grade work, with a low income, and non-home owners) had significantly higher odds of being below the health literacy competency threshold when compared with groups at lower risk of socioeconomic deprivation. Older people (45-65 years) had higher odds of being below the health literacy competency threshold (text-only) than younger people (16-44 years). Sex showed a different direction for literacyonly (males had higher odds of being below the thresholdl compared with literacy + numeracy Ifemales had higher odds of being below the threshold).

After adjustment, being born in the UK and not being in work were not significant; the effect of several other predictors remained statistically significant but was reduced.

The ATI index showed that those below the competency thresholds had significantly lower access to potential sources of health information in both unadjusted and adjusted analyses.

\section{DISCUSSION}

\section{Summary}

Sixty-four examples of health materials were sampled across five health activity areas. All 64 contained literacy (text) information, while 50 also contained numeracy information. No materials contained just numeracy information. The materials were written at a level of complexity above the skills of a significant proportion of the English working-age population. Of the 5795 participants who had completed the literacy skills tests, 2515 $(43 \%)$ were below the text-only competency threshold, while of the 4767 people who had completed both the literacy and numeracy skills assessments, 2905 (61\%) were below the literacy + numeracy competency threshold.

Analysis of $\mathrm{SDH}$ showed that all were highly statistically significantly associated with greater odds of being below the competency thresholds; the exception being age (literacy + numeracy competency). While not all variables remained in the multivariable models, both models showed strong associations with $\mathrm{SDH}$, with those already at risk of lower health through SDH also being at higher risk of low health literacy. Those with the most need for access to health information, that is, those below the competency thresholds, therefore had the least access to it. 
Table 3. Literacy competency univariable and multivariable analyses

\begin{tabular}{|c|c|c|c|c|c|c|}
\hline Category & $\begin{array}{l}\text { Unadjusted } \\
\text { odds ratio }\end{array}$ & $95 \% \mathrm{Cl}$ & $P$-value & $\begin{array}{l}\text { Adjusted } \\
\text { odds ratio }\end{array}$ & $95 \% \mathrm{Cl}$ & $P$-value \\
\hline \multicolumn{7}{|l|}{ Sex } \\
\hline Male & 1.20 & 1.08 to 1.33 & $<0.001$ & 1.25 & 1.09 to 1.43 & 0.001 \\
\hline \multicolumn{7}{|l|}{$\begin{array}{l}\text { Age, years } \\
16-44 \text { (ref) }\end{array}$} \\
\hline $45-65$ & 1.26 & 1.14 to 1.40 & $<0.001$ & 1.44 & 1.25 to 1.67 & $<0.001$ \\
\hline \multicolumn{7}{|l|}{$\begin{array}{l}\text { Ethnicity } \\
\text { White (ref) }\end{array}$} \\
\hline Black minority ethnic & 2.23 & 1.92 to 2.60 & $<0.001$ & 1.43 & 1.09 to 1.87 & 0.008 \\
\hline \multicolumn{7}{|l|}{ Nativity } \\
\hline Not born in UK & 2.18 & 1.88 to 2.53 & $<0.001$ & 1.07 & 0.75 to 1.51 & 0.719 \\
\hline \multicolumn{7}{|l|}{$\begin{array}{l}\text { First language } \\
\text { English (ref) }\end{array}$} \\
\hline Other than English & 3.34 & 2.78 to 4.00 & $<0.001$ & 2.03 & 1.39 to 2.97 & $<0.001$ \\
\hline \multicolumn{7}{|l|}{$\begin{array}{l}\text { Qualification level } \\
\geq 2 \text { (ref) }\end{array}$} \\
\hline$<2$ & 3.85 & 3.43 to 4.32 & $<0.001$ & 2.38 & 2.04 to 2.77 & $<0.001$ \\
\hline \multicolumn{7}{|l|}{ Employment } \\
\hline Not employed & 1.82 & 1.63 to 2.04 & $<0.001$ & 1.05 & 0.88 to 1.25 & 0.551 \\
\hline \multicolumn{7}{|l|}{ Job grade } \\
\hline Intermediate (ref) & 1.97 & 1.68 to 2.30 & $<0.001$ & 1.40 & 1.18 to 1.71 & $<0.001$ \\
\hline $\begin{array}{l}\text { Routine/manual/students/ } \\
\text { unemployed }\end{array}$ & 3.32 & 2.94 to 3.75 & $<0.001$ & 1.88 & 1.60 to 2.22 & $<0.001$ \\
\hline \multicolumn{7}{|l|}{ Income } \\
\hline$<€ 10000$ & 1.91 & 1.71 to 2.12 & $<0.001$ & 1.41 & 1.19 to 1.67 & $<0.001$ \\
\hline \multicolumn{6}{|l|}{ Home ownership } & \\
\hline Does not own home & 2.04 & 1.83 to 2.27 & $<0.001$ & 1.32 & 1.13 to 1.60 & $<0.001$ \\
\hline \multicolumn{7}{|l|}{$\begin{array}{l}\text { Area deprivation } \\
0-9 \text { (ref) }\end{array}$} \\
\hline $10-19$ & 1.50 & 1.29 to 1.75 & $<0.001$ & 1.25 & 0.97 to 1.60 & 0.075 \\
\hline $20-29$ & 1.92 & 1.61 to 2.28 & $<0.001$ & 1.46 & 1.16 to 1.83 & 0.001 \\
\hline $30-39$ & 2.95 & 2.44 to 3.57 & $<0.001$ & 1.58 & 1.28 to 1.96 & $<0.001$ \\
\hline$\geq 40$ & 4.04 & 3.37 to 4.85 & $<0.001$ & 1.94 & 1.54 to 2.46 & $<0.001$ \\
\hline \multicolumn{7}{|l|}{ Access to information score } \\
\hline \multicolumn{7}{|l|}{$\geq 9$ (ref) } \\
\hline $5-8$ & 2.21 & 1.94 to 2.51 & $<0.001$ & 1.78 & 1.51 to 2.11 & $<0.001$ \\
\hline$<5$ & 5.89 & 5.02 to 6.90 & $<0.001$ & 3.11 & 2.56 to 3.79 & $<0.001$ \\
\hline
\end{tabular}

Ref $=$ reference. impacts on their health should they fail to understand them. The literacy and numeracy competencies were determined from a recent large English national skills survey, purposively sampled to ensure representativeness for the working-age population.

The limitations of this study were as follows. Population skills were measured using tests of a type that, while widely used in national and international surveys, have been criticised for only partially measuring skills, not adequately reflecting different cultures, and not adequately reflecting 'real life'. ${ }^{21}$ However, the health materials used to determine competency thresholds were 'real-life' and representative of the wider range of health materials in everyday use.

This study did not assess important skills such as verbal literacy; however, the area that was examined in this study (the skills to fully understand and use health materials) is undoubtedly a core skill; people below the competency thresholds will have to use other resources, such as face-toface contacts with health professionals and family and social networks, to gather health information.

The SFL 2011 survey only assessed the skills of the population aged $16-65$ years. There are numerous studies showing the impact of low health literacy in older people: ${ }^{4,22,23}$ given cognitive decline with age, and the study's findings of lower health literacy in older people within the cohort in the SFL 2011 survey, it is likely that this group had an even greater unmet need.

Only a small proportion of available materials were sampled, although they were assessed as 'representative' by the study's panel of experts. In addition, locally produced materials not available nationally were not sampled; these may be written at a different level of complexity to those available nationally.

The framework used for sampling the health materials has been used in several national surveys of health literacy levels. ${ }^{6-8}$ While it is fairly comprehensive, the framework does not include health materials to support informed/shared decision making, thus materials in this important aspect of patient care were not sampled.

Because of funding and time limitations, the literacy and numeracy difficulty of health materials was only assessed by one reviewer; although any areas of ambiguity, or where assessment was 'borderline' between two skills levels, were highlighted and discussed. It is possible, therefore, that errors in assessment were not identified and corrected. 


\section{Comparison with existing literature}

The authors believe that this is the first study to describe a method for measuring the gap between health information complexity and the health literacy skills of the people for whom health information is designed. Despite the different methodology compared with other health literacy surveys, the proportion of the population with low health literacy is similar to that found in other industrialised countries. ${ }^{5-8}$

\section{Implications for research and practice}

In England, health materials are too complex for the skills of a significant proportion of the population, resulting in less access to health information. Further, those who are at the highest risk of poorer health (such as those from black and minority ethnic groups and with low-income, low status jobs) are most likely to have low health literacy. The health information needed by these groups will have to be provided by the NHS as they have the least access to other information sources.

The size and importance of the problem requires awareness and effective solutions.
GPs have a key role through patient care and through their roles as health service commissioners. Rigour should be applied to the development of health materials, to ensure they are written at accessible skills levels. Non-written forms of communication (audio, visual, internet) or use of mobile phone applications could be promoted, particularly for more vulnerable groups.

In the longer-term, the raising of general literacy and numeracy skills through schools and adult education will have health benefits in addition to better life skills.

To date, most health literacy studies have been observational; it is important to develop and test interventions to improve health literacy, and assess the impact on health. ${ }^{3}$ There have been limited numbers of health economic health literacy studies, with inconclusive results. ${ }^{3}$ With UK annual health expenditure at $€ 142.8$ billion, ${ }^{24}$ it is important to assess the impact of health literacy on healthcare costs, and to ensure that assessment of health literacy interventions includes an economic evaluation.

\section{Funding}

This study was funded by a research grant from Merck Sharp Dohme (MSD). The researchers are all independent from the funder (MSD). The study sponsor (MSD) was not involved in study design or the collection, analysis, and interpretation of data or the writing of the article or the decision to submit it for publication. Paul T Seed is partly funded by Tommy's (Registered charity no. 1060508).

\section{Ethical approval}

Not required.

\section{Provenance}

Freely submitted; externally peer reviewed.

\section{Competing interests}

The authors have declared no competing interests.

\section{Acknowledgements}

With thanks to the participants in the SFL 2011 survey, the external experts who reviewed the health materials and DBIS for allowing use of the SFL 2011 data.

\section{Discuss this article}

Contribute and read comments about this article: bjgp.org/letters 


\section{REFERENCES}

1. Nutbeam D. Health promotion glossary. Health Promot Int 1998; 13(4): 349-364.

2. Nutbeam D. Health literacy as a public health goal: a challenge for contemporary health education and communication strategies into the 21 st century. Health Promot Int 2000; 15(3): 259-267.

3. Berkman ND, Sheridan SL, Donahue KE, et al. Health literacy interventions and outcomes: an updated systematic review. AHRQ Publication No. 11-E006. Rockville, MD: Agency for Healthcare Research and Quality, 2011

4. Bostock S, Steptoe A. Association between low functional health literacy and mortality in older adults: longitudinal cohort study. BMJ 2012; 344: e1602.

5. European Health Literacy Project Consortium. Comparative report on health literacy in eight EU member states. HLS-EU, 2012. http:// www.maastrichtuniversity.n//web/file?uuid=d101b63c-dbbe-472d-971f7a4eae14ba47\&owner=d5b3681e-fc4a-476e-b9ff-a807c26760b9 laccessed 1 May 2015).

6. Australian Bureau of Statistics. Health literacy, Australia. Canberra: Australian Bureau of Statistics, 2006

7. Rudd RE. Health literacy skills of U.S. adults. Am J Health Behav 2007; 31 Suppl 1: S8-S18.

8. Canadian Council on Learning. Health literacy in Canada. A healthy understanding. Ottowa, ON: Canadian Council on Learning, 2008.

9. Rudd RE, Moeykens BA, Colton TC. Health and literacy: a review of medical and public health literature. In: Comings JP, Garner B, Smith C, eds. The annual review of adult learning and literacy. Volume 1. San Francisco, CA: Jossey-Bass Publishers, 2000: 158-199.

10. Rudd RE, Anderson JE, Oppenheimer S, et al. Health literacy: an update of medical and public health literature. In: Comings JP, Garner B, Smith C, eds. Review of adult learning and literacy. Volume 7. Mahwah, NJ: Lawrence Erlbaum Associates, 2007: 175-203.

11. US Department of Health and Human Services, Office of Disease Prevention and Health Promotion. National action plan to improve health literacy. Washington, DC: US Department of Health and Human Services, 2010.

12. Rudd R, Kirsch IS, Yamamoto K. Literacy and health in America. Princeton, NJ:
Education Testing Service, 2004

13. Health Literacy. About us. http://uww.healthliteracy.org.uk/ laccessed $11 \mathrm{Mar}$ 2015).

14. Qualifications and Curriculum Authority. The National Qualifications Framework. 2006. http://www.educationforhealth.org/data/files/qca framework.pdf laccessed $11 \mathrm{Mar} 2015)$

15. Committee on Performance Levels for Adult Literacy, Board on Testing and Assessment. Measuring literacy: performance levels for adults. Washington, DC Center for Education. Division of Behavioral and Social Sciences and Education. National Research Council (US), 2005.

16. Department for Business Innovation and Skills. The 2011 skills for life survey: a survey of literacy, numeracy and ICT levels in England. BIS Research paper number 81. London: Department for Business Innovation and Skills, 2012

17. Commission on Social Determinants of Health. Closing the gap in a generation Health equity through action on the social determinants of health. Final report of the Commission on Social Determinants of Health. Geneva: World Health Organization, 2008

18. The Marmot Review Team. Fair society, healthy lives: The Marmot Review. Strategic Review of Health inequalities in England post-2010. 2010. uww.ucl. ac.uk/marmotreview laccessed 11 Mar 2015).

19. Department for Communities and Local Government (England). The English Indices of Deprivation 2010. 2011. https://umw.gov.uk/government/statistics/ english-indices-of-deprivation-2010 (accessed 11 Mar 2015).

20. von Elm E, Altman DG. Egger M, et al. Strengthening the Reporting of Observational Studies in Epidemiology (STROBE) statement: guidelines for reporting observational studies. BMJ 2007; 335(7624): 806-808.

21. Hamilton M, Barton D. The international adult literacy survey: what does it really measure? International Review of Education 2000; 46(5): 377-389.

22. Baker DW, Wolf MS, Feinglass J, et al. Health literacy and mortality among elderly persons. Arch Intern Med 2007; 167(14): 1503-1509.

23. Wolf MS, Gazmararian JA, Baker DW. Health literacy and health risk behaviors among older adults. Am J Prev Med 2007; 32(1): 19-24.

24. Payne CS. Expenditure on healthcare in the UK: 2011. London: Office for National Statistics, 2013. 